\title{
Pattern of Adaptation and Teachers' Difficulties in Applying Thematic Learning Model Based on Curriculum 2013 in Teaching Learning process for Elementary Teachers in Malang, Indonesia
}

\author{
Yulita Pujiharti ${ }^{1}$, Amanah Agustin ${ }^{2}$, Suhartatik $^{3}$ \\ ${ }^{1,2,3}$ Faculty of Social Science and Humanity Education, Institute of Teacher Training and Education Budi Utomo \\ Malang, Indonesia
}

\begin{abstract}
The implementation of Curriculum 2013 has consequences for the teachers to comprehend and apply thematic learning model. The research objectives are (1) to know what kinds of learning model used by the Elementary Teachers in Malang, Indonesia after the implementation of curriculum 2013; (2) to analyse the teacher's difficulties in applying thematic learning model Based on Curriculum 2013 in teaching learning process for Elementary Teachers in Malang, Indonesia; (3) to know the "Pattern of Adaptation" used by the teachers in applying thematic learning model based on Curriculum 2013. The research design is Metaanalysis that combined quantitative and qualitative methods. In conclusion, most of 1st and 4th grade Elementary Teachers in Malang, Indonesia have implemented thematic learning model based on Curriculum 2013, except 6th grade teachers. The teachers find difficulties in implementation phase of Curriculum 2013 on aperception activities such as the connection between subjects and themes, and followed by preparing teaching media. Evaluation phase is the most difficult phase and take a long time for the teachers, because they have to select every subject score for each theme. The highest score is pattern of obedience followed by innovation pattern of curriculum 2013.
\end{abstract}

Keywords : Curriculum 2013, Pattern of Adaptation, Teachers' difficulties, Thematic Learning Model

\section{Introduction}

The development of Curriculum in 2013 is part of a strategy to improve the quality of education in Indonesia. The orientation of Curriculum 2013 is the improvement and the balance between the competencies of attitude, skill and knowledge. ( Undang-undang No.20 Tahun 2003 tentang Sistem Pendidikan Nasional) . At least, there are two major factors that will support the success of Curriculum 2013. Firstly, the suitability of teacher's and educator's competence versus curriculum and textbook. Secondly, the supporting factors which consist of three elements: (i) the availability of textbooks as teaching materials and learning resources that integrate forming curriculum standard; (ii) strengthening the role of government for guidance and supervision and (iii) strengthening the management and school culture.

The teachers are required to understand and use thematic learning model in Curriculum 2013. Thematic learning is learning activity that integrated the materials of many subjects in a theme or topic of discussion. Based on the results of previous studies, the researchers find out the fact that most of the teachers teach by using conventional learning models. Commonly, the teachers do not apply the innovative learning model.Moreover, many parties doubt about the ability of the teachers in implementing Curriculum 2013. (Cholili,Cholil, 2013)

The objectives of the study are (1) to know what kinds of learning model used by the Elementary Teachers in Malang, Indonesia after the implementation of Curriculum 2013; (2) to analyse the teacher's difficulties in applying thematic learning model Based on Curriculum 2013 in teaching learning process for Elementary Teachers in Malang, Indonesia; (3) to know the "Pattern of Adaptation" used by the teachers in applying thematic learning model based on Curriculum 2013.

\section{Curriculum 2013}

\section{Review of Literature}

Curriculum 2013 focuses on behavioral values, the value of personality, noble character, or better known as a dignified character education. It is a revision of the Curriculum 2006 that will further lead to the development of character. The new curriculum is administered for the academic year 2013-2014 starting from the primary level up to tertiary education.

The Ministry of Education and Culture evaluated that education in Indonesia need to be evaluated and changed the national curriculum. The evaluation is carried out thoroughly by considering four educational 
standards, namely graduation competency standards, content standards, processes standards, and evaluation standards.

Orientation of Curriculum 2013 is the improvement and the balance between attitude competence, skills and knowledge. Refers to the mandate of Law No. 20 Year 2003, as stated in the explanation of Article 35 " the graduation competence is qualified ability of graduates that cover attitudes, knowledge, and skills based on national standards that have been agreed".

Three other factors are the reason for Curriculum 2013 development are as follows:

1) Future challenges include globalization era, environmental issues, advances in information technology, the convergence of science and technology, and knowledge-based economy.

2) Future competencies cover the ability to communicate, the ability to think clearly and critically, the ability to consider the moral aspects of a problem, the ability to be effective citizens, and the ability to try to understand and tolerant of different views.

3) The social phenomenon appear as a student fights, drugs, corruption, plagiarism, cheating in various types of exams, and social unrest.

4) Public perception of education has been emphasized on cognitive aspects, the students' load is too heavy, and less charged character.

(Source: www.pppg.or.id.Pembelajaran Tematik. Download on 6 January 2014

\section{Teachers}

The teachers' task is more severe in implementation of Curriculum 2013. Because teachers is the deciding factor for the success of curriculum 2013. There are two major factor for the success of curriculum 2013 : (1) the decision maker, the suitability of teacher's competence and educators with curriculum and textbooks; (2) the supporting factors consists of three elements; (a) the availability of books as teaching materials and learning resources that integrate forming curriculum standards; (ii) strengthening the role of government for supervision and guidance; and (iii) strengthening management and school cultural. Refer to the urgency of the teachers, Ministry of National Education make strategy for the success of curriculum 2013 fully carried out by the teacher.

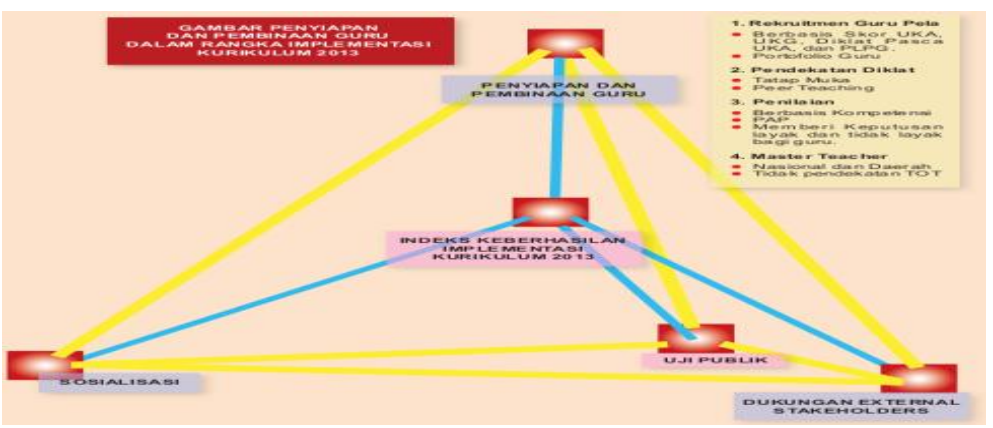

Figure 1 Teachers' preparation and construction in the implementation of Curriculum 2013 (Source: www.pppg.or.id. Pembelajaran Tematik. Download on 6 January 2014)

\section{Teachers' Pattern of Adaptation in Process of Thematic Learning Model Curriculum 2013}

Curriculum 2013 brings greatly changing in teaching learning process from the beginning of curriculum, it will be difficult for the teachers to adapt.

Table 1. Merton types of Adaptation :

\begin{tabular}{|l|l|l|}
\hline Model of Adaptation & Culture Goals & Institutionalized Means \\
\hline Conformity & + & + \\
\hline Innovation & + & - \\
\hline Habitualism (ritualism) & - & + \\
\hline Retreatism & - & - \\
\hline Rebellion & + & + \\
\hline
\end{tabular}

(Source: Richier G. and Douglas, 2004)

Pattern adaptation of conformity appear when the people receive both material success and cultural purposes in ways that are culturally justified to achieve that goal. Pattern adaptation of habitualism imply the abandonment or low ratings to the top of success while continuing to adhere the ways of justified. In adaptation pattern of retreatism, individuals reject both cultural goals and ways justified to achieve it without replacing the new norms. They exist in society, but it is not part of the community. 
The rebellion is the refusal of both cultural objectives and justified way to achieve the goals of culture, and replace them with new norms for individual adaptation based on their type.

All Mertonian perspective are relevant to the role of behavior only, it is not kind of personality . It is possible for the people to move from one model of adaptation to others.

\section{Research Road Map}

\section{Research Method}

Here is the road map of the research:

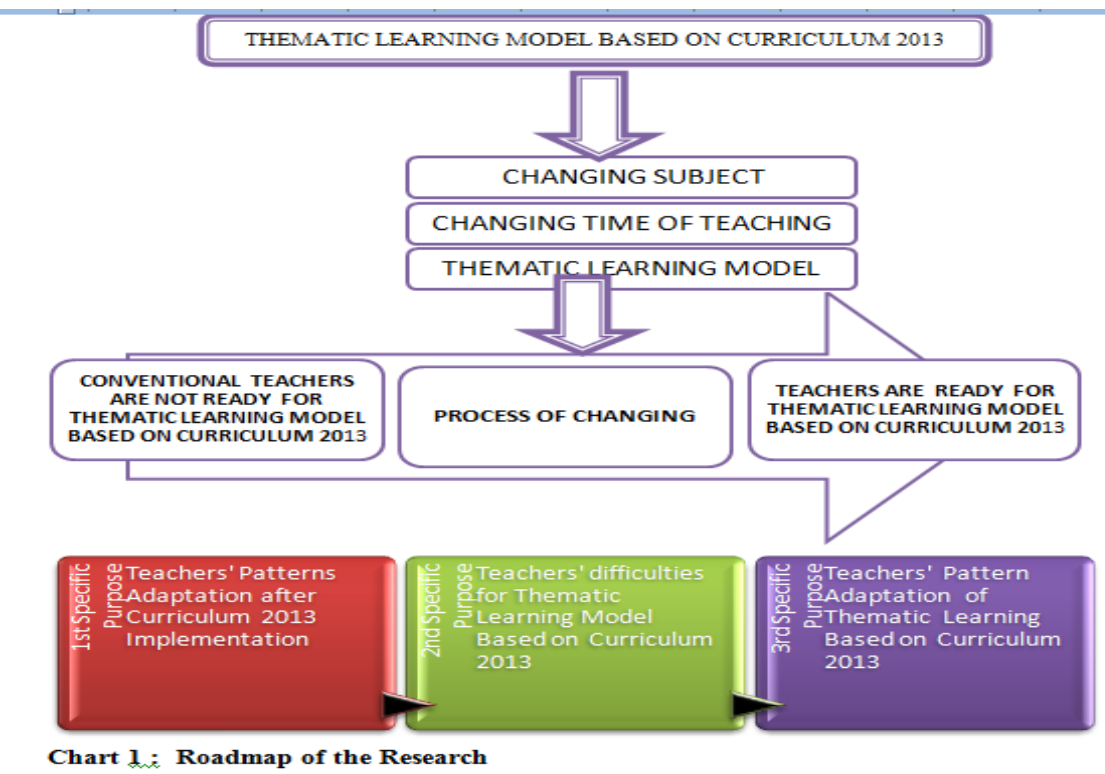

\section{Research Design}

The design of the research is meta-analyzes, the research model will combine qualitative research journal study, theory and conjecture from the government on the implementation of the curriculum 2013 with quantitative research in the field. The instrument was a questionnaire and a structured interview.( Slavin, Robert, 1995).

The population was an elementary school teachers who have run thematic learning of curriculum 2013 in Malang, Indonesia. The research sample are 75 elementary school teachers who have done thematic learningbased curriculum 2013 from five districts.

The research instruments are questionnaires, structured interviews based on the component of thematic learning model. Analysis of the data use the method of meta-analysis and descriptive. Deductive Descriptive test is used to assess the ability of teachers to implement thematic curriculum-based learning 2013. Meta analysis is used for teachers' pattern of adaptation .

\section{Teachers' understanding of Curriculum 2013}

\section{Finding and Discussion}

Based on research finding, all Public Elementary Schools in Malang has conducted thematic learning model based curriculum 2013, mainly for 1st grades and 4th grade. For Private Elementary School start to use curriculum 2013 on 2014. Most of the teachers are still adapt to use thematic learning model. Level of understanding Curriculum 2013 will be presented on Table 1.

From the table below, the high level of understanding if teachers had followed the training more than one time. The more often follow the training, teachers will be more understanding.

Table 2 .Level of Understanding Curriculum 2013 after Training

\begin{tabular}{|l|l|l|l|l|l|l|l|l|l|l|}
\hline & \multicolumn{4}{|c|}{ Total of Training } & sum & \%sum \\
\hline Level of Understanding & sum & $1 \mathrm{x} \%$ & sum & $2 \mathrm{x} \%$ & sum & $3 \mathrm{x} \%$ & sum & $4 \mathrm{x} \%$ & & \\
\hline Absolutely understand & 0 & 0.0 & 2.0 & 2.7 & 5.0 & 6.7 & 2.0 & 2.7 & 9.0 & 12.0 \\
\hline Understand & 8 & 10.7 & 13.0 & 17.3 & 9.0 & 12.0 & 0.0 & 0.0 & 30.0 & 40.0 \\
\hline Moderately understand & 10 & 13.3 & 10.0 & 13.3 & 5.0 & 6.7 & 1.0 & 1.3 & 26.0 & 34.7 \\
\hline Less understand & 4 & 5.3 & 4.0 & 5.3 & 1.0 & 1.3 & 0.0 & 0.0 & 9.0 & 12.0 \\
\hline Strongly not understand & 0 & 0.0 & 1.0 & 1.3 & 0.0 & 0.0 & 0.0 & 0.0 & 1.0 & 1.3 \\
\hline percentage & 22 & 29.3 & 30.0 & 40.0 & 20.0 & 26.7 & 3.0 & 4.0 & 75.0 & 100.0 \\
\hline
\end{tabular}


The implementation Phase and Level Difficulty of the Teachers in Implementing Curriculum 2013

In implementation phase, 1st grade and 4th grade teachers find the same problems in separation of subjects, to connect between one subject to others on the same theme, the teacher should be able to make the connecting narrative.

Table 3. Teacher's difficulties Level in Implementing Curriculum 2013

\begin{tabular}{|l|l|l|l|}
\hline Level of Difficulty & sum & $\%$ \\
\hline $44.0-50.4$ & Very Difficult & 6 & 8.0 \\
\hline $50.5-56.8$ & Difficult & 26 & 34.7 \\
\hline $56.9-63.2$ & Neutral & 21 & 28.0 \\
\hline $63.3-69.6$ & Easy & 9 & 12.0 \\
\hline $69.7-76.0$ & Very Easy & 13 & 17.3 \\
\hline & & 75 & 100.0 \\
\hline
\end{tabular}

The table show that $34.7 \%$ teachers find difficulties to administer curriculum 2013. The hardest thing is technique assessment, it is too long and takes time for teachers. The assessment results also eliminates the competitive spirit of students, because it can no longer be used as a classroom rank. The following is the description level of difficulty for the teachers in implementing curriculum 2013.

Table 4 Level of Teacher's Difficulties in Preparation of Curriculum 2013

\begin{tabular}{|l|l|l|l|l|l|l|l|l|l|l|l|}
\hline Preparation & Difficult & $\%$ & Neutral & $\%$ & Easy & $\%$ & Very Easy & $\%$ & Sum & $\%$ \\
\hline 1 & Making Syllabus & 0 & 0.0 & 0 & 0.0 & 67 & 89.3 & 8 & 10.7 & 75 & 100. \\
\hline 2 & Making Lesson Plant & 5 & 6.7 & 56 & 74.7 & 12 & 16.0 & 2 & 2.7 & 75 & 100. \\
\hline
\end{tabular}

From the table above it can be concluded that on preparation phase, the teachers does not find some problems because all provided by the government, and teachers' community.

Table 5 Teacher's Level of difficulty on Implementation Phase of Curriculum 2013

\begin{tabular}{|c|c|c|c|c|c|c|c|c|c|c|c|}
\hline \multicolumn{2}{|c|}{ Implementation } & Difficult & $\%$ & Neutral & $\%$ & Easy & $\%$ & Very Easy & $\%$ & Sum & $\%$ \\
\hline 1 & Aperception Activity & 34 & 45.3 & 27 & 36.0 & 12 & 16.0 & 2 & 2.7 & 75 & 100. \\
\hline 3 & Learning Model & 31 & 41.3 & 32 & 42.7 & 10 & 13.3 & 2 & 2.7 & 75 & 100. \\
\hline 5 & Questions & 12 & 16.0 & 50 & 66.7 & 12 & 16.0 & 1 & 1.3 & 75 & 100. \\
\hline 6 & Motivation Model & 25 & 33.3 & 35 & 46.7 & 12 & 16.0 & 3 & 4.0 & 75 & 100. \\
\hline 7 & Closing Activity & 5 & 6.7 & 54 & 72.0 & 14 & 18.7 & 2 & 2.7 & 75 & 100. \\
\hline
\end{tabular}

The Implementation Phase of Curriculum 2013, most teachers have difficulty in aperception activities. In this phase $45.3 \%$ of teachers find very difficult, $36 \%$ easy and moderate. Moreover $50 \%$ of teachers find difficulties to implement learning activity based on lesson plan.

Tabel 6 Teacher's Level of difficulty on Evaluation Phase of Curriculum 2013

\begin{tabular}{|l|l|l|l|l|l|l|l|l|l|l|l|}
\hline \multicolumn{2}{|l|}{ Evaluation Phase } & Difficult & $\%$ & Neutral & $\%$ & Easy & $\%$ & Very Easy & $\%$ & Sum & $\%$ \\
\hline 1 & Examination & 44 & 58.7 & 28 & 37.3 & 3 & 4.0 & 0 & 0.0 & 75 & 100 \\
\hline 2 & Raw score Evaluation & 58 & 77.3 & 15 & 20.0 & 2 & 2.7 & 0 & 0.0 & 75 & 100 \\
\hline 3 & Score Selection & 60 & 80.0 & 11 & 14.7 & 4 & 5.3 & 0 & 0.0 & 75 & 100 \\
\hline
\end{tabular}

Based on the above table it can be concluded that teachers find difficulties in performing the assessment of Curriculum 2013.

Tabel 7 Teacher's availabilities to implement Curriculum 2013 or School-based Curriculum

\begin{tabular}{|l|l|l|l|l|l|l|l|}
\hline & $\begin{array}{l}\text { Teachers availabilities to } \\
\text { implement Curriculum }\end{array}$ & School-based Curr & $\%$ & Curr 2013 & $\%$ & sum & $\%$ \\
\hline 1 & Klojen Area & 11 & 14.7 & 4 & 5.3 & 15 & 20.0 \\
\hline 2 & Belimbing Area & 10 & 13.3 & 5 & 6.7 & 15 & 20.0 \\
\hline 3 & Sukun Area & 10 & 13.3 & 5 & 6.7 & 15 & 20.0 \\
\hline 4 & Kdkandang Area & 12 & 16.0 & 3 & 4.0 & 15 & 20.0 \\
\hline 5 & Lowokwaru Area & 15 & 20.0 & 0 & 0.0 & 15 & 20.0 \\
\hline & Total & 58 & 77.3 & 17 & 22.7 & 75 & 100.0 \\
\hline
\end{tabular}

The table shows that $77.3 \%$ of teachers are more available with School-based Curriculum (KTSP). For the first and second grade level are still easy to administer thematic learning model, but the higher class level will be more difficult to implement. 
Pattern of Adaptation and Teachers' Difficulties in Applying Thematic Learning Model Based on...

Table 8. Agree or Disagree the Changing of School-Based Curriculum to Curriculum 2013

\begin{tabular}{|c|l|l|l|l|l|l|l|}
\hline & $\begin{array}{l}\text { The Changing of School- } \\
\text { Based Curr to Curr2013 }\end{array}$ & Agree & $\%$ & Disagree & $\%$ & Sum & $\%$ \\
\hline 1 & Klojen Area & 6 & 8.0 & 9 & 12.0 & 15 & 20.0 \\
\hline 2 & Belimbing Area & 5 & 6.7 & 10 & 13.3 & 15 & 20.0 \\
\hline 3 & Sukun Area & 2 & 2.7 & 13 & 17.3 & 15 & 20.0 \\
\hline 4 & Kdkandang Area & 3 & 4.0 & 12 & 16.0 & 15 & 20.0 \\
\hline 5 & Lowokwaru Area & 2 & 2.7 & 13 & 17.3 & 15 & 20.0 \\
\hline & Total & 18 & 24.0 & 57 & 76.0 & 75 & 100.0 \\
\hline
\end{tabular}

Table 8. Agree or Disagree of Changing Subjects to Theme

\begin{tabular}{|l|l|l|l|l|l|l|l|}
\hline & Changing Subjects to Theme & Agree & $\mathbf{\%}$ & Disagree & \% & Sum & \% \\
\hline 1 & Klojen Area & 4 & 5.3 & 11 & 14.7 & 15 & 20.0 \\
\hline 2 & Belimbing Area & 3 & 4.0 & 12 & 16.0 & 15 & 20.0 \\
\hline 3 & Sukun Area & 5 & 6.7 & 10 & 13.3 & 15 & 20.0 \\
\hline 4 & Kdkandang Area & 3 & 4.0 & 12 & 16.0 & 15 & 20.0 \\
\hline 5 & Lowokwaru Area & 0 & 0.0 & 15 & 20.0 & 15 & 20.0 \\
\hline & Total & $\mathbf{1 5}$ & $\mathbf{2 0 . 0}$ & $\mathbf{6 0}$ & $\mathbf{8 0 . 0}$ & $\mathbf{7 5}$ & $\mathbf{1 0 0 . 0}$ \\
\hline
\end{tabular}

Based on the questionnaire almost $80 \%$ of the teachers do not agree to change subject matters to theme.

Tabel 9. Teacher's perception about "Do the curriculum 2013 can change student's behavior"

\begin{tabular}{|l|l|l|l|l|l|l|l|l|l|}
\hline & $\begin{array}{l}\text { Change } \\
\text { behavior, }\end{array}$ & $\begin{array}{l}\text { Major } \\
\text { Change }\end{array}$ & $\%$ & $\begin{array}{l}\text { Moderate } \\
\text { Change }\end{array}$ & $\%$ & $\begin{array}{l}\text { No } \\
\text { Change }\end{array}$ & sum & $\%$ \\
\hline 1 & Klojen Area & 4 & 5.3 & 4 & 5.3 & 7 & 9.3 & 15.0 & 20.0 \\
\hline 2 & Belimbing Area & 1 & 1.3 & 6 & 8.0 & 8 & 10.7 & 15.0 & 20.0 \\
\hline 3 & Sukun Area & 6 & 8.0 & 6 & 8.0 & 3 & 4.0 & 15.0 & 20.0 \\
\hline 4 & Kdkandang Area & 2 & 2.7 & 8 & 10.7 & 5 & 6.7 & 15.0 & 20.0 \\
\hline 5 & Lowokwaru Area & 2 & 2.7 & 8 & 10.7 & 5 & 6.7 & 15.0 & 20.0 \\
\hline & Total & 15 & 20.0 & 32 & 42.7 & 67.0 & 37.3 & 75 & 100.0 \\
\hline
\end{tabular}

Based on teachers' perception $37.3 \%$ stated that curriculum 2013 will be able to change the behavior of students. Teachers are optimistic that the curriculum can change the behavior of students in 2013 to $20 \%$, and teachers who feel "moderate change" is $42.7 \%$.

Teachers' Pattern of Adaptation to Curriculum 2013

Pattern of Adaptation in Malang 64\% is a pattern of compliance. In Kedungkandang and Klojen areas, the Pattern of Adaptation compliance is bigger than the other districts. The next pattern is $29.3 \%$ for innovation.

Tabel 10. Teacher's Pattern of Adaptation to Curriculum 2013

\begin{tabular}{|l|l|l|l|l|l|l|l|l|l|l|l|l|}
\hline $\begin{array}{l}\text { Pattern of } \\
\text { Adaptation }\end{array}$ & $\begin{array}{l}\text { Klojen } \\
\text { Area }\end{array}$ & $\%$ & $\begin{array}{l}\text { Blim } \\
\text { bing } \\
\text { Area }\end{array}$ & $\%$ & $\begin{array}{l}\text { Kd.kan } \\
\text { dang } \\
\text { Area }\end{array}$ & $\%$ & $\begin{array}{l}\text { Lowok } \\
\text { waru } \\
\text { Area }\end{array}$ & $\begin{array}{l}\% \\
\text { Sukun } \\
\text { Area }\end{array}$ & $\begin{array}{l}\text { Malan } \\
\text { g City } \\
\%\end{array}$ \\
\hline Conformity & 11 & 73.3 & 8 & 53.3 & 12 & 80.0 & 7 & 46.7 & 10 & 66.7 & 48 & 64.0 \\
\hline Innovation & 2 & 13.3 & 6 & 40.0 & 3 & 20.0 & 6 & 40.0 & 5 & 33.3 & 22 & 29.3 \\
\hline $\begin{array}{l}\text { Habitualism } \\
\text { (ritualism) }\end{array}$ & 0 & 0.0 & 1 & 6.7 & 0 & 0 & 0 & 0 & 0 & 0 & 1 \\
\hline Retreatism & 2 & 13.3 & 0 & 0.0 & 0 & 0 & 0 & 0 & 0 & 0 & 2.3 & 2.7 \\
\hline Rebellion & 0 & 0.0 & 0 & 0.0 & 0 & 0 & 2 & 0 & 0 & 0 & 2 & 2.7 \\
\hline Total & 15 & 100 & 15 & 100 & 15 & 100 & 15 & 86.7 & 15 & 100 & 75 & 100 \\
\hline
\end{tabular}

\section{Conclusion}

Refers to the objectives of the study, Thematic Learning Model Based on Curriculum 2013 are performed by Elementary School teachers in Malang for 1st grade and 4th grade, while another grades have been implemented the curriculum 2013 step by step, for the 6th grades are still using Scholl-based Curriculum (KTSP).

In the preparation phase, $89.3 \%$ teachers create syllabus and lesson plans easily. On the stage of implementation, most of teachers have difficulties in aperception activities.

In the evaluation phase is the most difficult phase and time-consuming for teachers. $58.7 \%$ teachers find difficulties to administer the exam, while teachers find difficulties to assess existing raw score of $77.3 \%$ and for sorting the score each subject per theme is $80 \%$. 


\section{References}

[1] 2003.Undang-undang No.20 Tahun 2003 tentang Sistem Pendidikan Nasional. Badan Standar Nasional Pendidikan

[2] _www.pppg.or.id.Pembelajaran Tematik. Download on 6 January 2014

[3] _ Rancangan Pembelajaran Tematik Kurikulum 2013,REP | 08 January 2013 | Download on 6 January 2014

[4] Cholili,Cholil, Mindset Memaksimalkan Kurikulum Baru, OPINI|04 January 2013 Download on 6 January 2014

[5] Dedi Supriadi. 1998. Mengangkat Citra dan Martabat Guru. Yogyakarta: Adicita

[6] Degeng, I. N. S. 1991. Karakteristik Belajar Siswa Berbagai Perguruan Tinggi. Laporan Penelitian. Depdikbud Dikti PTBAU/IUC

[7] Lemlech. J. K., 1994. Curriculum and Instructional Methods for the Elementary and Middle School (Third Edition). New York:Macmillan College Publishing Company.

[8] Richier G. and Douglas JG.2004.Teori Sosiologi Modern.Jakarta : Prenada Media

[9] Mutmainah Laily. Guru Konvensional, lib.uin-malang.ac.id/thesis/chapter_i/07140016

[10] Orlich, Donal C., et al. 1998. Teaching Strategies: A Guide to Better Instruction (5 ${ }^{\text {th }}$ edition). New York: Houghton Mifflin Company.

[11] Sisdiknas, Pergeseran Paradigma Belajar Abad 21,www.kemendiknas.go.id Posted Thu, 12/06/2012 - 10:26

[12] Sisdiknas,Keberhasilan Kurikulum2013, kemendiknas go.id Posted 12/26/2012 - 10:11 download on 5 January 2014

[13] Idi,Abdullah.2010. Pengembangan Kurikulum, Teori dan Praktek. Jogjakarta : AR Ruzz Media

[14] Urip, Metode Mengajar Kuno Masih Eksis, www.urip.wordpress.com,10 Mei 2012 download on 5 January 2014

[15] Merryfield, Merry M., Ellaine Jarchow, and Sarah Pickert (1997).Preparing teachers to teach global perspectives : A Handbook for teacher educators. California: Carwin Press, Inc.

[16] Slavin, Robert E. 1995.Cooperative learning, Theory, Research, and Pactice (2 $2^{\text {nd }}$ d). Boston: Allyn and Bacon. 